Article

\title{
Comparative Effectiveness of Different Phase Change Materials to Improve Cooling Performance of Heat Sinks for Electronic Devices
}

\author{
Ahmad Hasan ${ }^{1, *}$, Hassan Hejase ${ }^{1}$, Shaimaa Abdelbaqi ${ }^{1}$, Ali Assi ${ }^{2}$ \\ and Mohammed O. Hamdan ${ }^{3}$ \\ 1 College of Engineering, United Arab Emirates University, P.O. Box 15551 Al Ain, United Arab Emirates; \\ hhejase@uaeu.ac.ae (H.H.); 200734406@uaeu.ac.ae (S.A.) \\ 2 College of Engineering, Lebanese International University, P.O. Box 146404 Beirut, Lebanon; \\ ali.assi@liu.edu.lb \\ 3 College of Engineering, American University of Sharjah, P.O. Box 26666 Sharjah, United Arab Emirates; \\ mohammadh@uaeu.ac.ae \\ * Correspondence: ahmed.hassan@uaeu.ac.ae; Tel.: +971-55-5454069
}

Academic Editor: Mohammed Mehdi Farid

Received: 16 June 2016; Accepted: 2 August 2016; Published: 26 August 2016

\begin{abstract}
This paper thermo-physically characterizes salt hydrate, paraffin wax and milk fat as phase change materials (PCMs). The three PCMs are compared in terms of improving heat sink (HS) performance for cooling electronic packaging. An experimental study is carried out on commercially available finned HS with and without PCM under natural ventilation (NV) and forced ventilation $(\mathrm{FV})$ at different heat loads $(4 \mathrm{~W}$ to $10 \mathrm{~W}$ ). The results indicate that integration of all of the PCMs into the HS improves its cooling performance; however, milk fat lags behind the other two PCMs in terms of cooling produced. A three-dimensional pressure-based conjugate heat transfer model has been developed and validated with experimental results. The model predicts the parametric influence of PCM melting range, thermal conductivity and density on HS thermal management performance. The HS cooling performance improves with increased density and conductivity while it deteriorates with the wider melting range of the PCMs.
\end{abstract}

Keywords: milk fat; calcium chloride hexahydrate; paraffin wax; phase change material; cooling; electronic packaging

\section{Introduction}

Phase change materials (PCMs) are potential temperature regulators in electronic devices. They absorb the heat generated by the device as latent heat during duty period and release it to the ambient during off-duty period. The heat exchange occurs reversibly at isothermal conditions [1,2], which can restrict the device temperature within the desired range [3]. The time duration for the PCM heat storage varies depending on the PCM's thermo-physical properties [4] thus making the choice of an optimum PCM crucial. The cooling effect produced by integrating PCMs into electronic packaging has been widely studied numerically and experimentally [5-9]. The integration of PCM into aluminum foam with conductive fins has yielded better cooling performance than natural ventilation cooling and aluminum foam only cooling $[7,8]$. The design optimization of a latent heat thermal management system (LHTMS) concluded a relationship between the number of fins, fin spacing, HS volume and heat generation rates [9]. The most commonly used PCMs for thermal management of electronics are salt hydrates [10] and paraffin waxes [11,12] because they are abundantly available at low cost [13].

The most attractive characteristics of salt hydrates are their higher latent heat of fusion [14], higher thermal conductivity of $0.6 \mathrm{~W} /(\mathrm{m} \cdot \mathrm{K})[15,16]$, negligible volume change during phase transition [16], 
favorable transition temperatures [17], and lower cost [18]. The salt hydrates are abundantly available [19] in large quantities as by-products of industrial processes [14,20] and as waste co-products in many chemical processes including production of soda ash [21].

The main problems with salt hydrates as temperature regulators are their lower thermal stability [22,23], chemical instability [14], corrosion to metals [23,24], incongruent melting [22] and sub-cooling below the solidification temperature [24]. The incongruence can be solved by mechanical stirring, using excess water to prevent forming a supersaturated solution from melted crystals and modification of their chemical composition. Mechanical stability can be improved by PCM encapsulation to reduce separation. Sub-cooling is suppressed by addition of thickening agents and nucleating agent such as borax [13]. However, high-density borax may settle down when added into PCM [25], which may require further investigation to solve this problem.

Paraffin waxes have suitable thermo-physical properties such as higher heat of fusion [26], lower corrosion rates to metals [27] and negligible sub-cooling with no phase segregation [28]. Such characteristics allow paraffin to withstand multiple thermal cycles with no substantial change in their thermo-physical properties. Paraffin waxes as PCMs do possess the disadvantage of a lower thermal conductivity of $0.20 \mathrm{~W} /(\mathrm{m} \cdot \mathrm{K})$, higher volume expansion during melting-freezing up to $15 \%$, convective currents, fumes discharge at high temperature [29] and a lower density of $800 \mathrm{~kg} / \mathrm{m}^{3}$ [30] which occupies more volume and requires larger containment size for PCM housing which will add additional weight to the system and will reduce energy storage density. The thermal conductivity can be improved by addition of metallic and carbon nano-tube/fiber fillers to render them effective temperature regulators [31,32].

Milk fat is introduced as a PCM being human-friendly [33], with favorable thermo-physical properties of thermal conductivity being $0.29 \mathrm{~W} /(\mathrm{m} \cdot \mathrm{K})$ [34] and density being $911 \mathrm{~kg} / \mathrm{m}^{3}$. Milk fat is a water-in-oil emulsion resulting from an inversion of the cream [33] containing different fatty acid, esters and glycerol with a wide melting from $-40{ }^{\circ} \mathrm{C}$ to $40^{\circ} \mathrm{C}[34,35]$. The molecular formula of butter is $\mathrm{CH}_{3}\left(\mathrm{CH}_{2}\right)_{16} \mathrm{COOH}$ and $\mathrm{CH}_{3}\left(\mathrm{CH}_{2}\right)_{7} \mathrm{CH}=\mathrm{CH}\left(\mathrm{CH}_{2}\right)_{7} \mathrm{COOH}$ [36] for stearic acid and oleic acid, respectively.

Since milk fat has never been used as PCM, its key data of heat of fusion are not widely reported. Raw butter melts over a wide range and would need clarification to achieve milk fats usable as PCM. The current research intends to characterize the clarified butter (milk fat onwards) as PCM and compares its performance with traditional salt hydrates and paraffin waxes.

\section{Materials and Methodology}

The conventional electronic components are designed to operate over a specified temperature range with upper limits generally set at $70{ }^{\circ} \mathrm{C}$ for commercial applications, $85{ }^{\circ} \mathrm{C}$ for industrial applications, and $125^{\circ} \mathrm{C}$ for military applications [37]. Most electronic devices operate optimally at $60^{\circ} \mathrm{C}$ [38] for safety reasons. Some electronic devices operate continuously while the rest operate over a short time and have an idle cycle. The PCM-based cooling technique is deemed more suitable for devices operating periodically as the duty cycle will absorb heat in melting PCM and regulate device temperature while the idle cycle will allow the PCM to release the stored heat and solidify to be used for the proceeding duty cycle.

\subsection{Materials}

The PCM selection criteria were based on the melting point being few degrees higher than room temperatures, as, under non-operation conditions, the electronic devices are kept near room temperature. Milk fat possesses such optimum a melting peak $24-34{ }^{\circ} \mathrm{C}$ reasonably above the room temperature. Two known PCMs were selected with melting peaks closer to that of milk fat, namely salt hydrate-calcium chloride hexahydrate with melting peak from $29-30^{\circ} \mathrm{C}$ and a commercial grade of paraffin wax RT-42 with melting peak $37-41{ }^{\circ} \mathrm{C}$ to compare the performance of milk fat with known materials. 
The butter used in this research contains: cow's milk fat (80\%), bacterial culture, natural Butter, unsalted lactic butter, milk solid non-Fat $(2 \%)$ and moisture $(18 \%)$. To clarify the butter, the butter was allowed to solidify slowly. All the froth formed on the top surface was skimmed off until a clear yellow layer on top of milky layer appeared. The yellow layer was carefully drawn using syringe. Finally, a very fine mesh strainer was used to get a clarified milk fat leaving the milky residue in the container.

A Differential Scanning Calorimetry (DSC-Q200, TA INSTRUMENTS, New Castle, DE, USA) is used to determine the thermo-physical properties of melting point, melting range and latent heat of fusion for the PCM. A 5-mg PCM sample is heated from $0{ }^{\circ} \mathrm{C}$ to $70{ }^{\circ} \mathrm{C}$ at a heating rate of $5{ }^{\circ} \mathrm{C} / \mathrm{min}$ to determine its thermo-physical properties. At the end of each heating run, liquid nitrogen is used to cool down the DSC pans to $0^{\circ} \mathrm{C}$ in preparation for the next run with new sample.

\subsection{Methodology}

\subsubsection{Experimental Setup}

The HS under study is designed as an aluminum rectangular enclosure (51 $\mathrm{mm} \times 21 \mathrm{~mm} \times 25 \mathrm{~mm})$ to avoid the leakage problem during the melting stage of the PCMs. HS is accommodating equally spaced $(1.6 \mathrm{~mm})$ vertically aligned rectangular fins. The four lateral walls and top cover of HS are 1-mm thick aluminum sheets. Figure 1A depicts the schematic diagram of the thermal management experimental setup, while Figure 1B shows a zoomed section of the HS enclosure.
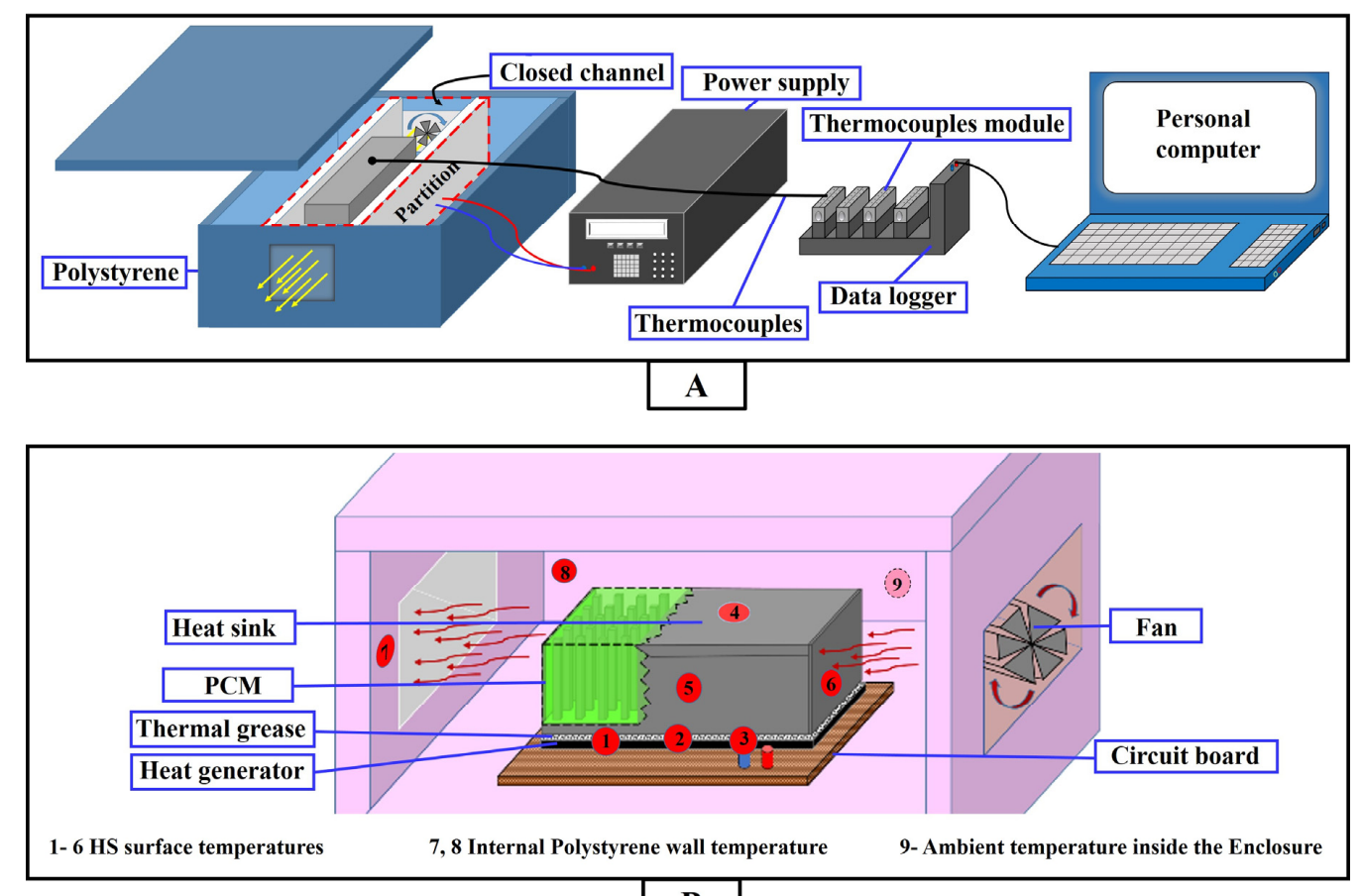

B

Figure 1. Schematic diagram of the whole thermal management experimental setup (A); and zoomed in section of heat sink (HS) enclosure (B).

The heat generator (RCHB-10ND, Digi-Key Electronics, Thief River Falls, MN, USA) is connected to a DC Power Supply (PPT-3615, Stantronic Instruments, Northampton, UK) to apply the heat load. The heat is conducted from heat generator surface to HS surface contacted through a thin sandwich layer of conductive thermal interface material $(K=3.8 \mathrm{~W} /(\mathrm{m} \cdot \mathrm{K})[39]$ intended to reduce the contact resistance. Calibrated K-type (Chromel-Alumel) thermocouples with an error within $\pm 0.5^{\circ} \mathrm{C}$ are installed at different HS locations, as shown in Figure 1B, to measure the transient temperature rise. A 1.6 W DC fan (259-1547-ND, Digi-Key Electronics, Thief River Falls, MN, USA) is applied to 
ventilate the HS at an air exchange rate of 9.9 Cubic feet per minute $(\mathrm{CFM})$ at $25^{\circ} \mathrm{C}$. A Mini-Vane CFM Anemometer (AN340, Extech Instruments by Flir, Townsend West Nashua, NH, USA) measures air velocity past the HS walls. The test setup is thermally guarded in an insulated compartment employing $10 \mathrm{~cm}$-thick EPS (Expanded Polystyrene) insulator sheets with a thermal conductivity of $0.042 \mathrm{~W} /(\mathrm{m} \cdot \mathrm{K})$ to assure stable ambient conditions. The data are logged using an NI Compact-RIO Data Acquisition System (NI DAQ Pro-cDAC-9174, National Instruments, Austin, TX, USA) interfaced with Lab-VIEW GUI on a dedicated computer.

\subsubsection{Experimental Procedure}

The experiments are conducted at $4-10 \mathrm{~W}$ power input to heat generator which mimics the heat fluxes generated in medium to high heat intensity electronics [40] at $25{ }^{\circ} \mathrm{C}$ ambient temperature and 101 Pa pressure are applied in each of experimental run. The same volumetric amount of each PCM $(10 \mathrm{~mL})$ is contained in the HS equivalent to $15 \mathrm{~g}$ of salt, $8 \mathrm{~g}$ of paraffin wax and $9 \mathrm{~g}$ of milk fat. The contained PCM possessed total heat storage capacity of $3.24 \mathrm{~kJ}, 1.15 \mathrm{~kJ}$ and $0.56 \mathrm{~kJ}$ for salt, paraffin and milk fat, respectively (considering peak between $18-30^{\circ} \mathrm{C}$ in case of milk fat). The HS base temperatures $\left(T_{\mathrm{b}}\right)$ are measured under natural as well as forced ventilation modes with and without PCM, as summarized in Table 1. Each experiment started at $10^{\circ} \mathrm{C}$ with PCM in solid state and is repeated three times to assure the repeatability of data under the same conditions.

Table 1. Experimental modes of operation.

\begin{tabular}{ccc}
\hline \multicolumn{2}{c}{ Operation Mode } & Description \\
\hline \multirow{4}{*}{ Natural ventilation } & Ref-NV & Empty heat sink under natural ventilation \\
& Salt-NV & Heat sink filled with salt hydrate under natural ventilation \\
& Paraffin-NV & Heat sink filled with paraffin under natural ventilation \\
& Milk fat-NV & Heat sink filled with milk fat under natural ventilation \\
\hline \multirow{5}{*}{ Forced ventilation } & Ref-FV & Empty heat sink under forced ventilation \\
& Salt-FV & Heat sink filled with salt hydrate under forced ventilation \\
& Paraffin-FV & Heat sink filled with paraffin heated under forced ventilation \\
& Milk fat-FV & Heat sink filled with milk fat under forced ventilation \\
\hline
\end{tabular}

\subsubsection{Uncertainties of the Experimental Setup}

The experimental nature of this work requires the disclosure of the measurement errors (presented in Table 2) to give insight into the accuracy of the experiments.

Table 2. Experimental uncertainties.

\begin{tabular}{cc}
\hline Equipment & Measurement Error \\
\hline Thermocouples & $\pm 0.05^{\circ} \mathrm{C}$ \\
Data Logger Module & $0.02{ }^{\circ} \mathrm{C}$ \\
Power Supply & $10 \mathrm{mV}, 1 \mathrm{~mA}$ \\
Thermal Grease & $0.000015 \mathrm{~m}^{2} \cdot{ }^{\circ} \mathrm{C} / \mathrm{W}$ \\
Anemometer & $\pm 3 \%$ \\
\hline
\end{tabular}

\subsection{Numerical Simulation}

A three-dimensional finite-volume conjugate heat transfer model is developed to model the problem numerically and validate the experimental results. The geometrical model is uniformly meshed using symmetric square cells as depicted in Figure 2. A mesh independent study is carried out to optimize the cell size regarding accuracy and computation cost, resulting in $0.5 \mathrm{~mm}$ square cells and 79,745 nodes. Table 3 summarizes the sizing criteria for the HS model. 


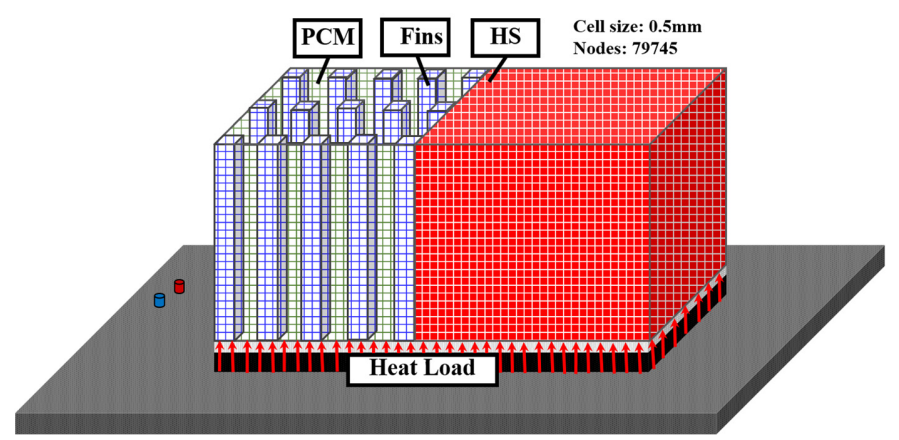

Figure 2. Meshing of the heat sink-phase change material (HS-PCM) system showing HS base plate, fins, PCM and side walls.

Table 3. Sizing criteria for the heat sink model.

\begin{tabular}{cc}
\hline Sizing Criteria & Description \\
\hline Size function & Curvature \\
Relevance Center & Fine \\
Smoothing & High \\
Growth rate & 1.2 \\
Nodes & 79,745 \\
\hline
\end{tabular}

The PCM is treated as incompressible fluid since no pressure induced volume changes are expected in the computational domain with melt flow. The model ignores marginal effects such as the volume changes in PCM after phase transition [29], natural convection within melted PCM [41] and floating/sinking of solid dendrites within melted PCM caused by buoyancy [41].

The model assumes a uniform heat flux conducted from heat generator to HS bottom surface. The remaining HS surfaces are regarded as imperfectly insulated system boundaries exchanging heat to the ambient by convection and radiation as will be explained in Sections 2.3.1 and 2.3.2.

\subsubsection{Phase Change Modeling}

An implicit enthalpy-porosity approach employing lever rule [42] is applied to model the phase change. The thermos-physical properties of the PCM are assumed to be independent of temperature. Porosity values at each iteration estimate the melt fraction which is 0 for fully solid, 1 for fully liquid and between 0 and 1 for mushy PCM. The three-dimensional energy Equations (1)-(3) governing phase change are explained below:

$$
\frac{\partial}{\partial t}\left(\rho c_{p} T\right)=\frac{\partial}{\partial x}\left(K \frac{\partial T}{\partial x}\right)+\frac{\partial}{\partial y}\left(K \frac{\partial T}{\partial y}\right)+\frac{\partial}{\partial z}\left(K \frac{\partial T}{\partial z}\right)+S_{h}
$$

The change in enthalpy $(H)$ is given by the Equation (2).

$$
\frac{d}{d t}(\rho H)=-\frac{d}{d_{x_{j}}}\left(\rho \mathrm{u}_{j} c_{p} T\right)+\frac{d}{d_{x_{j}}}\left[K \frac{d T}{d_{x_{j}}}\right]+S_{h}
$$

The parameters $\rho, \mathrm{u}_{j}, c_{\mathrm{p}}$ and $K$ denote the density, velocity vector, specific heat capacity and thermal conductivity of the PCM, respectively, whereas $S_{h}$ is the source term.

The liquid fraction ( $\beta$ ) of the PCM during phase change is calculated from Equation (3) [43]:

$$
\beta=\left\{\begin{array}{cl}
0, & \text { if } T<T_{\text {sol }} \\
\frac{T-T_{\text {sol }},}{T_{\text {liq }}-T_{\text {sol }},} & \text { if } T_{\text {sol }}<T<T_{\text {liq }} \\
1, & \text { if } T>T_{\text {liq }}
\end{array}\right.
$$


where $T_{\text {sol }}$ and $T_{\text {liq }}$ represent the solidus and liquidus temperatures of the PCM, respectively. $\beta$ is computed from the total enthalpy of the PCM given in Equation (4):

$$
H=H_{r e f}+\int_{T_{r e f}}^{T} c_{p} d T+\beta L
$$

where $L$ is the latent heat of fusion and $T_{\text {ref }}$ is the reference temperature.

The phase change problem is modeled and solved in ANSYS platform (Version 15, Computer software company, Cecil Township, PA, USA, 2015). The solver constantly iterates Equations (2)-(4) to determine the temperature at each node. The solution is updated every one-second time step with 20 iterations per time step for a total flow time of $35 \mathrm{~min}$.

The enthalpy-porosity approach is employed due to its single domain formulation, which eliminates computationally expensive explicit tracking of solid-liquid interface [44]. However, the limitation is that the solver does not distinguish between melting and solidification temperatures, which may cause discrepancies, especially during solidification $[45,46]$.

\subsubsection{Thermal Boundary Conditions}

A total of six thermal boundary conditions are applied considering HS exterior surfaces to be system boundaries depicted in Figure 3. The HS bottom surface is identified as the input heat flux boundary while the remaining five surfaces are marked as mixed-mode heat loss boundaries employing radiation and convection heat loss coefficients represented by Figure 3.

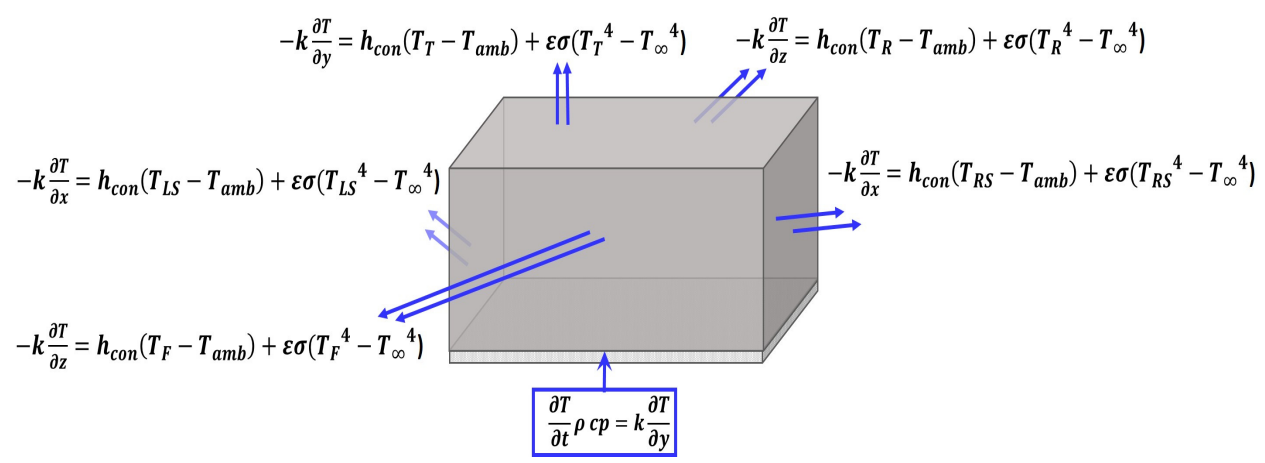

Figure 3. HS boundary conditions.

The convection heat loss is computed from Equation (5) as:

$$
Q_{c o n}=h_{\text {con }} \times A\left(T_{\text {Sur }}-T_{\text {amb }}\right)
$$

The convective heat loss coefficients for the HS surfaces are calculated by applying the Nusselt number $(\mathrm{Nu})$ relationship:

$$
h_{\text {con }}=\frac{K}{L} N u
$$

with $K$ and $L$ being the conductivity of air and characteristic length, respectively.

The horizontal and vertical surfaces of the HS are treated as plates subjected to uniform heat flux and the $N u$ correlation for plates are applied as given in Equations (7) and (8) [47]:

$$
\begin{aligned}
& N u_{\text {horiz }}=0.453 \operatorname{Re}_{L}^{0.5} \operatorname{Pr}^{\frac{1}{3}} \\
& N u_{\text {vert }}=0.664 \operatorname{Re}_{L}^{0.5} \operatorname{Pr}^{\frac{1}{3}}
\end{aligned}
$$

where $P r$ is the Prandtl number calculated from fundamental air properties as 


$$
\operatorname{Pr}=v c_{p} / K
$$

The Reynolds number $\left(R e_{L}\right)$ is calculated using the relation

$$
R e_{L}=\frac{V L}{v}
$$

where $v$ and $V$ denote the viscosity and air velocity, respectively.

The film temperature is calculated as the average of surface and ambient temperatures as

$$
T_{f}=\frac{\left(T_{\text {sur }}+T_{a m b}\right)}{2}
$$

The radiative heat loss is calculated from Stefan-Boltzmann law:

$$
Q_{\text {rad }}=\sigma \varepsilon\left(T_{\text {Sur }}{ }^{4}-T_{\infty}{ }^{4}\right)
$$

where $\sigma$ is the Stephan-Boltzmann constant, $\varepsilon=0.97$ is the external emissivity, $T_{\text {Sur }}$ is the surface temperature of HS sides and $T_{\infty}$ is the infinity temperature.

\section{Results and Discussion}

\subsection{Material Thermo-Physical Characterization}

The DSC hysteresis curves for the three PCMs, namely salt hydrate, paraffin wax and milk fat (refer to Appendix A) are interpreted to obtain PCM thermo-physical properties. The thermo-physical properties of interest for each material are summarized in Table 4 . The table shows that the salt hydrate has the highest latent heat of fusion $(L)$ with narrow melting range (desired), whereas milk fat has the lowest $L$ with wider melting range (undesired). It is very obvious that salt hydrate has superior thermal energy storage compared to the other two PCMs, however the availability, lower cost, lower corrosion rates and human friendliness of the paraffin and milk fat can justify their use as PCMs compared with salt hydrates. Milk fat shows the least heat of fusion which is mainly because the heat of fusion in the melting peak between 18 and $28^{\circ} \mathrm{C}$ is considered by the DSC calculation while milk fat melts over a wider range of $10-42{ }^{\circ} \mathrm{C}$. In case the thermal energy storage by milk fat over the whole melting range is considered, it may compare with that of paraffin wax.

Table 4. Thermo-Physical properties of phase change materials (PCMs) characterized by differential scanning calorimetry (DSC).

\begin{tabular}{ccccc}
\hline \multicolumn{2}{c}{ Materials } & Salt Hydrate & Paraffin & Milk Fat \\
\hline Thermal conductivity $\left(\mathrm{W} / \mathrm{m} \cdot{ }^{\circ} \mathrm{C}\right)$ & $0.60[48]$ & $0.20[49]$ & $0.29[34]$ \\
Specific heat capacity $\left(\mathrm{kJ} / \mathrm{kg} \cdot{ }^{\circ} \mathrm{C}\right)$ & $2.0[48]$ & $2.0[49]$ & $2.3[35]$ \\
Density $\left(\mathrm{kg} / \mathrm{m}^{3}\right)$ & & $1500[48]$ & $802[49]$ & $911[50]$ \\
Viscosity $(\mathrm{kg} / \mathrm{m} \cdot \mathrm{s})$ & & $0.00184[48]$ & $0.003[49]$ & $0.045[51]$ \\
\hline \multirow{2}{*}{ Solidus temperature $\left({ }^{\circ} \mathrm{C}\right)$} & Catalogue & $27[48]$ & $38[49]$ & $10[35]$ \\
& DSC & 28 & 38 & 10 \\
\hline \multirow{2}{*}{ Liquidus temperature $\left({ }^{\circ} \mathrm{C}\right)$} & Catalogue & $32[48]$ & $43[49]$ & $40[35]$ \\
& DSC & 32 & 43 & 40 \\
\hline \multirow{2}{*}{ Latent heat of fusion $(\mathrm{kJ} / \mathrm{kg})$} & Catalogue & $200[48]$ & $140[49]$ & - \\
& DSC & 214 & 142 & 60 \\
\hline Material source & & Rubitherm (SP-29) & Rubitherm (RT-42) & Kerry Gold \\
\hline
\end{tabular}




\subsection{Thermal Management Experiment}

The experiments consist of a heating run followed by a cooling run. The heating run lasted until $T_{b}$ reached the maximum temperature in all cases with and without PCM referring to steady state. The maximum temperature happened to be different at each power input level as it reached steady state. The heating run is followed by a cooling run until $T_{b}$ stabilizes below $25^{\circ} \mathrm{C}$ reaching steady state with ambient indicating that PCM had completely solidified in case of HS with PCM.

\subsubsection{Heating Run}

From DSC analysis, the lowest solidus temperature exhibited by the PCMs is $10{ }^{\circ} \mathrm{C}$ (milk fat). All the heating runs therefore started from the lowest solidification temperature $\left(10^{\circ} \mathrm{C}\right)$ to assure all PCMs being fully solid at start. Figure 4 shows the transient temperature profile for each tested case at a heat load of $4 \mathrm{~W}$.

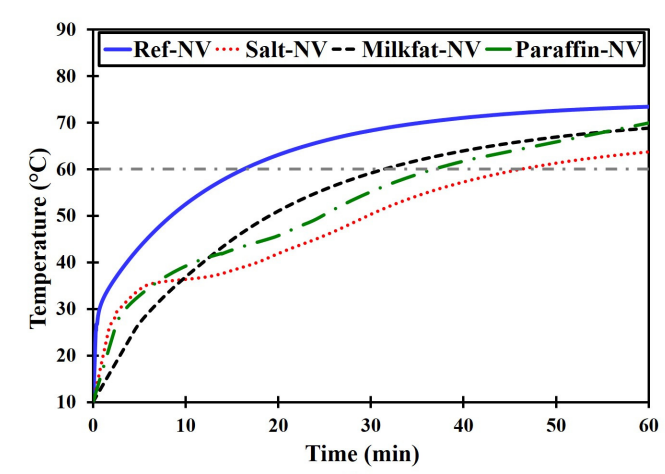

(A)

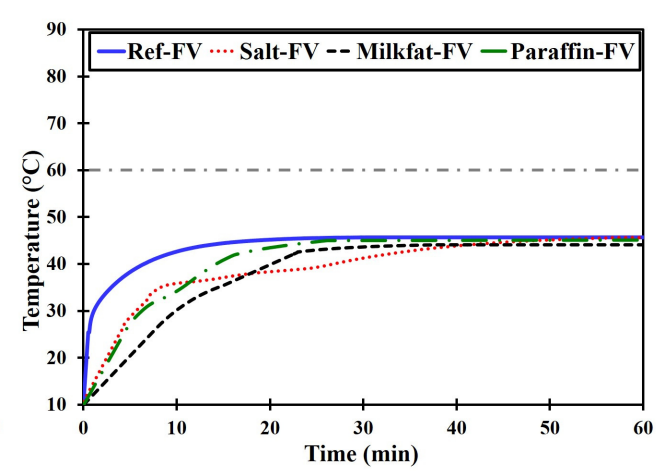

(B)

Figure 4. Time-temperature profile on the HS base surface for the complete heating run for three PCMs subjected to: (A) Natural ventilation (NV); and (B) Forced Ventilation (FV) at heat load of 4 W.

In the case of Ref-NV shown in Figure $4 \mathrm{~A}$, the $T_{b}$ rapidly rises above the $60^{\circ} \mathrm{C}$ threshold, the safety temperature limit for most of the electronics [37]. The inclusion of PCMs (represented by Salt-NV, Milk fat-NV and Paraffin-NV) induces a drop and time lag in the said temperature rise. The temperature drop happened due to increased thermal mass by virtue of PCM's latent heat of fusion and increase in specific heat capacity. It can be seen in Figure 4A that milk fat maintained lower temperature for first few minutes compared to salt hydrate and paraffin wax. However, over a longer time period, the salt hydrate outperformed both the paraffin wax and milk fat. The salt performs better because of higher density, higher heat of fusion $(L)$ and higher thermal conductivity $(K)$ compared to the other two PCMs. Paraffin wax and milk fat performed similarly. It is worthy to highlight that milk fat starts melting at $10{ }^{\circ} \mathrm{C}$ (below room temperature), while the electronic devices operate normally at room temperature $\left(25^{\circ} \mathrm{C}\right)$. It indicates that milk fat may remain partially melted in electronic devices even prior to the start of the device operation. Figure $4 \mathrm{~B}$ compares the temperature regulation performance of PCMs under FV for the same (6-10 W) heat loads. It is evident that the FV with PCM achieved lower temperature compared to NV with PCM due to increased convection heat losses [18,25]. Under FV, milk fat produced the highest cooling for $20 \mathrm{~min}$. mainly due to lower melting start $\left(10^{\circ} \mathrm{C}\right)$ indicating that a lower melting point PCM can better perform with FV. On the other hand, paraffin does not show a clear phase transition under FV because its melting point is very close to the highest steady state temperature.

To understand the effectiveness of each PCM for different operation times, $T_{b}$ is compared for short (5 min), average (15 $\mathrm{min}$ ) and longer $(60 \mathrm{~min})$ duty times, as shown in Figure 5A-E for heat loads $(4-10 \mathrm{~W})$ covering intensities ranging from $4027 \mathrm{~W} / \mathrm{m}^{2}$ to $9748 \mathrm{~W} / \mathrm{m}^{2}$. Figure $5 \mathrm{~A}$ shows that for short time (5 min) the HS with PCMs (Paraffin-NV, Salt-NV and Milk fat-NV) maintained lower temperatures by $6-10{ }^{\circ} \mathrm{C}$ compared to the HS only (Ref-HS). Note that HS only restricted the temperature below 
$60{ }^{\circ} \mathrm{C}$ at lower heat loads (4-6 W) while at higher heat loads $(8-10 \mathrm{~W})$, the device temperature rises above $60^{\circ} \mathrm{C}$ and would need additional cooling for safe operation. It shows that inclusion of PCM under $\mathrm{NV}$ can maintain the device temperature below or near $60^{\circ} \mathrm{C}$ up to $10 \mathrm{~W}$. Comparing between PCMs, milk fat (Milk fat-NV) maintained the lowest temperature up to $8 \mathrm{~W}$.

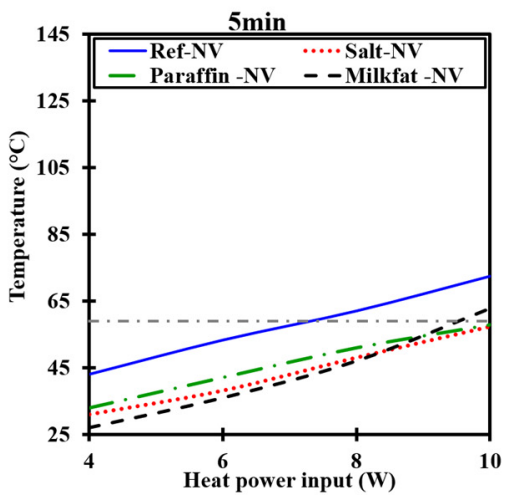

(A)

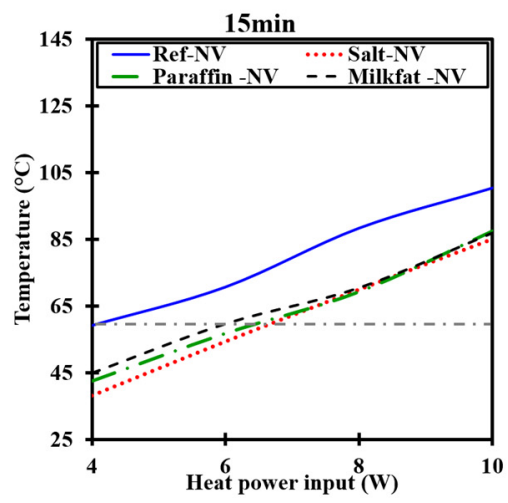

(B)

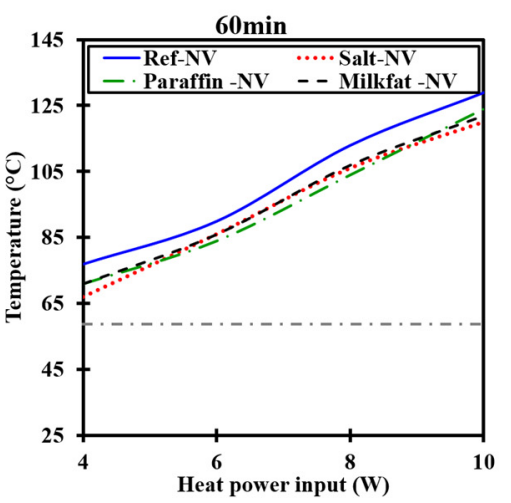

(C)

Figure 5. Average heat sink base surface temperature $\left(T_{b}\right)$ for three PCMs at 4-10 W heat loads under NV for: (A) $5 \mathrm{~min}$; (B) $15 \mathrm{~min}$; and (C) $60 \mathrm{~min}$.

Figure 5B shows that for a moderate time ( $15 \mathrm{~min}$ ) the HS only under NV cannot restrict the device temperature under safety limit $\left(60^{\circ} \mathrm{C}\right)$ and would not be advisable to use. However, when the PCMs are included in HS, the device can be maintained below safety limit only at lower heat loads (4-6 W). Figure 5B shows that salt hydrate maintained the lowest temperature while milk fat reached the highest temperature. Furthermore milk fat becomes least effective at prolonged operation time mainly due to lower $L$ and $\rho$ compared to salt hydrate.

Figure $5 \mathrm{C}$ shows that for substantially longer time $(60 \mathrm{~min})$ neither HS only nor the HS with PCMs under NV would restrict the device temperature below safety thus the device would always need the FV. This can be explained by the fact that for longer operation times, the PCMs get completely melted (retains no latent heat) therefore temperature curves for HS only and HS with PCMs come closer which is evident in Figure 5C.

Figure 6A shows that, under FV for $5 \mathrm{~min}$, the device temperature can be maintained below safety limit by HS only (Ref-FV) up to $8 \mathrm{~W}$; however, addition of PCMs (salt-FV, paraffin-FV and Milk fat-FV) extended it to $10 \mathrm{~W}$. PCMs rendered an additional temperature drop as compared to HS only under FV. In comparing PCMs' performance, milk fat performed better than the other two PCMs from $4 \mathrm{~W}$ to $8 \mathrm{~W}$, but the trend reversed at $10 \mathrm{~W}$.

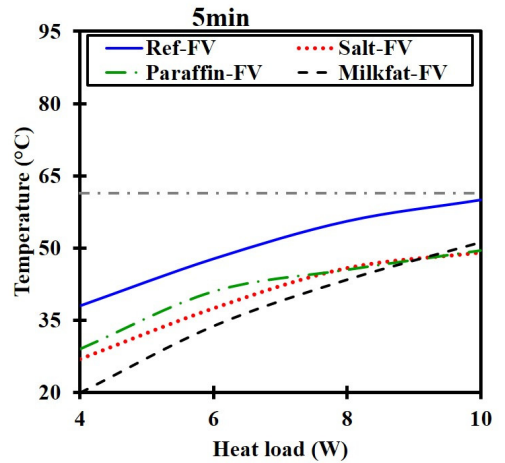

(A)

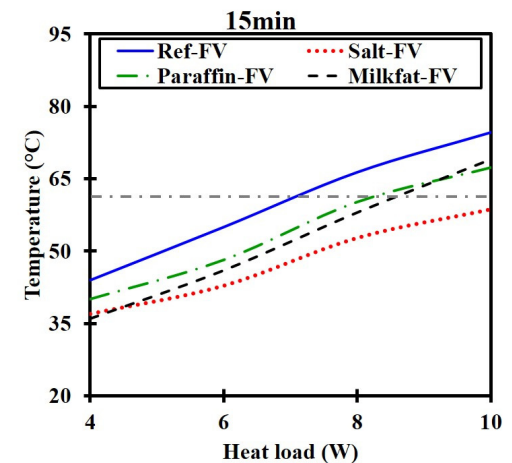

(B)

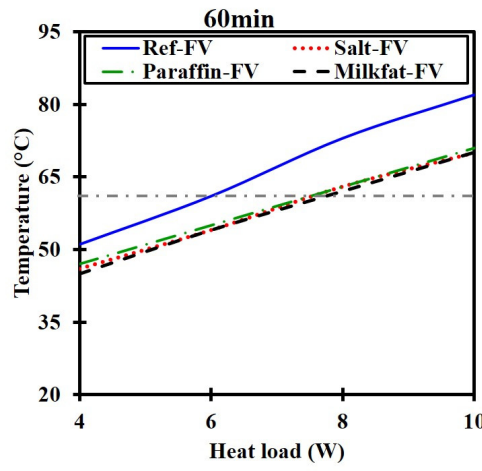

(C)

Figure 6. Average heat sink base surface temperature $\left(T_{b}\right)$ for three PCMs at $4-10 \mathrm{~W}$ heat loads under FV for: (A) $5 \mathrm{~min}$; (B) $15 \mathrm{~min}$; and (C) $60 \mathrm{~min}$ at heat loads. 
Figure 6B shows that for a longer operation time of $15 \mathrm{~min}$, HS only under FV can maintain the device below safety temperature up to $6 \mathrm{~W}$. The inclusion of PCM extends service to higher heat loads of $8 \mathrm{~W}$ for all PCMs and $10 \mathrm{~W}$ in the case of salt hydrate. For a $15 \mathrm{~min}$ period, salt hydrate performs better than the other PCMs.

Figure $6 \mathrm{C}$ shows that for a prolonged operation of $1 \mathrm{~h}$, the HS-only under FV maintains the device under safety temperature at a lower heat input of $4 \mathrm{~W}$ while adding PCMs can extend it to $6 \mathrm{~W}$. At heat loads above $8 \mathrm{~W}$, the device temperature will exceed safety limit and hence will be prone to failures. It can be emphasized that at higher heat loads additional measures would be needed, e.g., increasing the amount of PCM, increasing thermal conductivity of PCMs, improving contact resistance between HS and heat generator and increasing ventilation rates. Figure 7 summarizes the optimum cooling techniques as a function of operation time and heat loads.

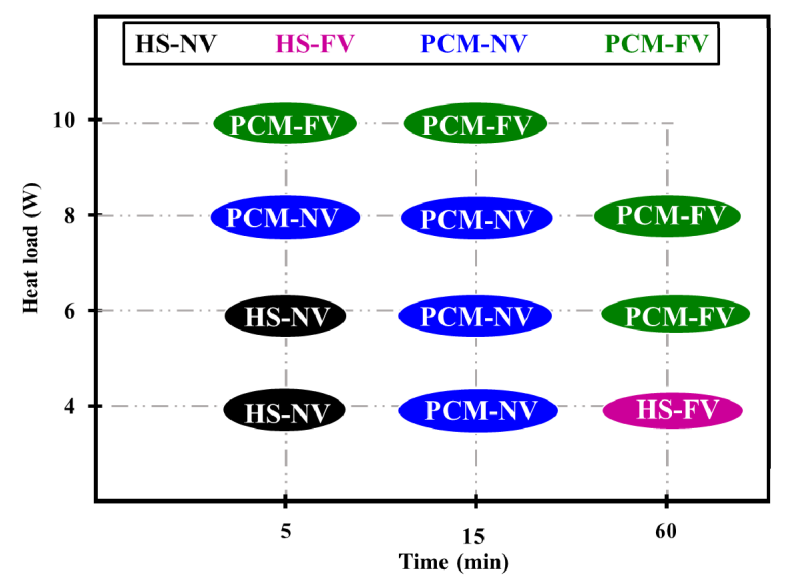

Figure 7. The optimum cooling techniques depending on operation time and heat load.

In order to compare the PCM cooling performance over the whole duration of experiments, average temperature drop (ATD) achieved by each PCM is presented in Figure 8 at 4-10 W heat loads under NV and FV. In the case of NV, using salt hydrate (red bars) achieved the highest ATD value $\left(15^{\circ} \mathrm{C}\right)$ due to higher $\rho, K$ and $L$, while milk fat (milk fat-NV) showed lowest ATD $\left(7-8^{\circ} \mathrm{C}\right)$ at all tested heat loads. In the case of FV, the salt hydrate achieved the highest ATD reaching up to $33^{\circ} \mathrm{C}$ at heat loads of $10 \mathrm{~W}\left(9748 \mathrm{~W} / \mathrm{m}^{2}\right)$ compared to the other two PCMs. However, at $4 \mathrm{~W}$ heat load, milk fat achieved a slightly higher $\operatorname{ATD}\left(19^{\circ} \mathrm{C}\right)$ compared to salt hydrate $\left(17^{\circ} \mathrm{C}\right)$ while the paraffin showed the lowest $\operatorname{ATD}\left(13^{\circ} \mathrm{C}\right)$.
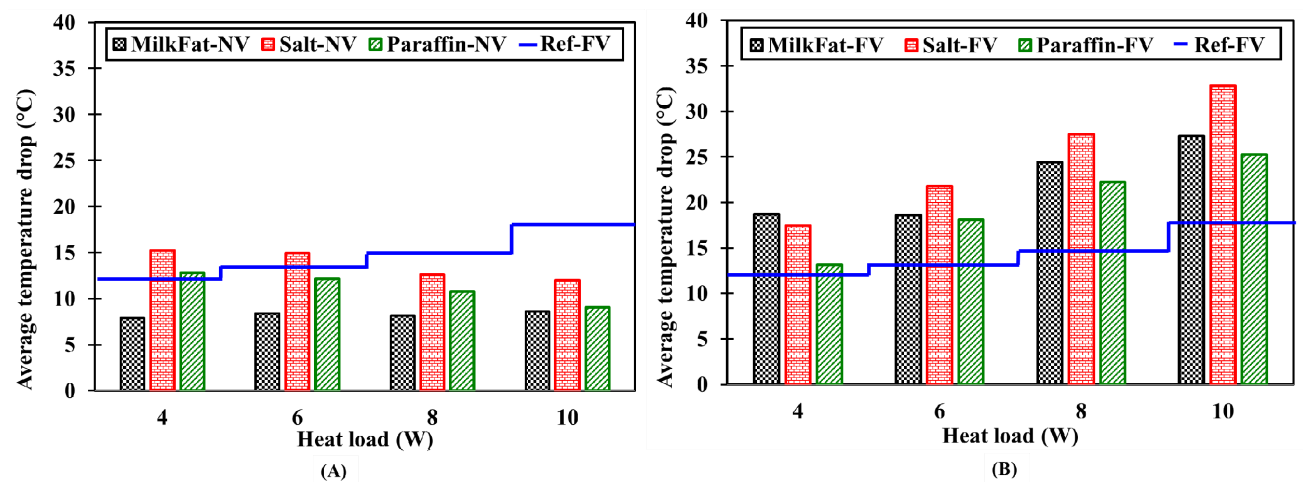

Figure 8. Average temperature difference (ATD) at the HS surface for the operational modes compared to the reference for different PCMs (salt hydrate, paraffin and milk fat subjected to: (A) NV; and (B) FV at heat power input of $(4 \mathrm{~W}, 6 \mathrm{~W}, 8 \mathrm{~W}$ and $10 \mathrm{~W})$. 


\subsubsection{Cooling Run}

The cooling curves for PCMs under NV and FV are presented in Figures 9-11 to study PCM regeneration to solid state for a comprehensive understanding of PCM performance. Figure 9 presents the cooling curve for paraffin wax when cooled from $50{ }^{\circ} \mathrm{C}$ under $\mathrm{NV}$ and $\mathrm{FV}$.

Figure 9 shows that under NV the paraffin wax starts solidification at $40^{\circ} \mathrm{C}$ and completes it at $34{ }^{\circ} \mathrm{C}$ with a wide solidification range of $6{ }^{\circ} \mathrm{C}$. However, in the case of $\mathrm{FV}$, the start and end of solidification are not evident due to rapid heat removal so that the phase change boundaries cannot be traced.

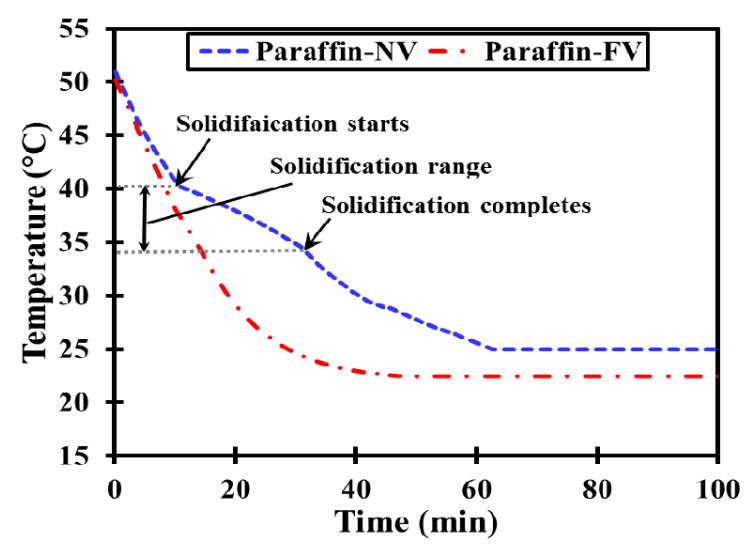

Figure 9. Transient cooling curve for paraffin represented by HS bottom surface temperature under NV and FV.

Figure 10 shows that salt hydrate starts solidification at $25^{\circ} \mathrm{C}$ and finishes at $24{ }^{\circ} \mathrm{C}$ with a narrow melting range of $1^{\circ} \mathrm{C}$. However, salt hydrate has to sub-cool down to $17^{\circ} \mathrm{C}$ before it starts solidification. This phenomenon reduces the utility of the salt hydrate, as it would need salt to be cooled far below room temperature $\left(25^{\circ} \mathrm{C}\right)$, at which the electronic devices typically operate. Adding extra water can prevent the formation of the heavy anhydrous salt that can suppress sub-cooling but reduces the heat storage intensity of the PCM [17]. Addition of nucleating agents such as borax [26] can suppress the sub-cooling effect but it settles down due to higher density, and thus further research is required to solve this problem [27].

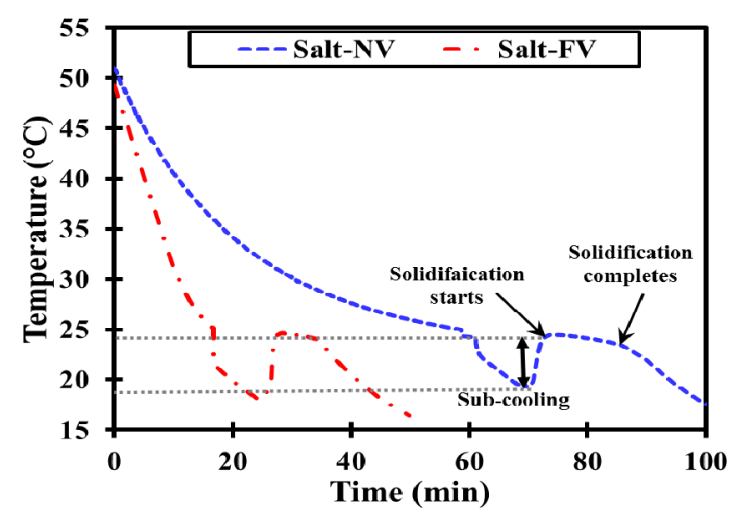

Figure 10. Transient cooling curve for salt represented by HS bottom surface temperature under NV and FV.

Figure 11 indicates that milk fat did not show any clear phase change since the melting range was very wide $\left(10-40{ }^{\circ} \mathrm{C}\right)$ and could find it difficult to regenerate. This problem can be solved by refining milk fat samples to retain only contents with the higher melting point and narrow melting 
range, which will be studied further. Results show that milk fat and paraffin wax do not exhibit such sub-cooling effect and would offer an advantage over salt hydrate during regeneration back to solid (if melting range for butter is fixed which is potentially easy to realize).

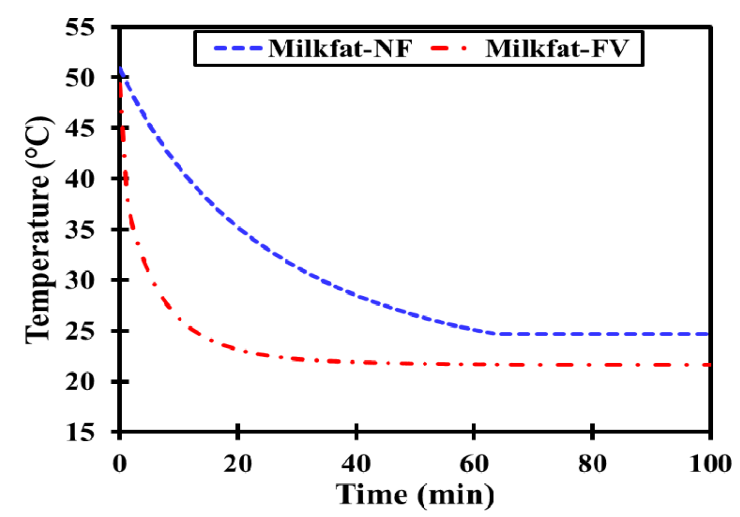

Figure 11. Transient cooling curve for milk fat represented by HS bottom surface temperature under $\mathrm{NV}$ and FV.

It is generally observed that the PCM takes less time to complete melting and regulate electronic temperature than it takes to get back to solid to be ready for the next heating cycle. In case of $4 \mathrm{~W}$, the time to complete melting:solidification was $27 \mathrm{~min}: 85 \mathrm{~min}$ for salt hydrate, $21 \mathrm{~min}: 33 \mathrm{~min}$ for paraffin wax while it is difficult to indicate the melting and solidification time for milk fat due to its wide melting range. This suggests that the PCM would be used for shorter time for temperature regulation than it would have to be idle to release heat. It also clearly suggests that the PCM based cooling technology cannot be applied for continuous device operation. Such technology only suits applications with periodic working/idle cycles. The time taken to melt and solidify depends on the heating/cooling rates, the nature of the PCM, the amount of the PCM and ambience around the PCM which would be optimized for each specific case in future research.

\subsection{Numerical Results}

\subsubsection{Numerical Validation}

This section compares experimental results with numerical predictions at $4 \mathrm{~W}$ heat load under NV for all PCMs. Figure 12 shows the experimental and numerical transient temperature for $35 \mathrm{~min}$ for salt hydrate (Figure 12A), paraffin (Figure 12B) and milk fat (Figure 12C).

Figure 12A clearly shows a good agreement between the experimental and simulation results in the melting regimes. However, after melting, the curves deviated slightly which can be attributed to under-prediction of heat losses at higher temperatures. The disagreement observed is not potentially important as, for cooling applications, the PCMs will not generally be used after their phase change is completed.

Figure 12B also shows good agreement between experimental and simulation results for paraffin wax with slightly lower melting point of actual PCM than applied in the model. Consequently, the paraffin wax starts melting earlier over a wider range in the experiment than predicted in the numerical simulation and causes a temperature variation by few degrees during the melting stage. In addition, a similar deviation as in Figure 12A was observed after the melting is completed. The temperature differences between experimental and simulation data for paraffin wax may stem from the bubble propagation and release observed at higher temperatures due to the natural convection currents [14]. 


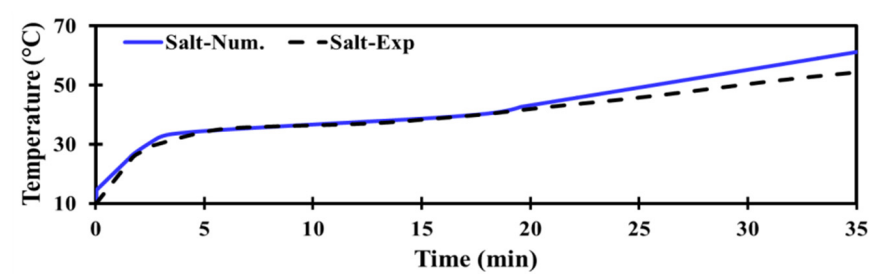

(A)

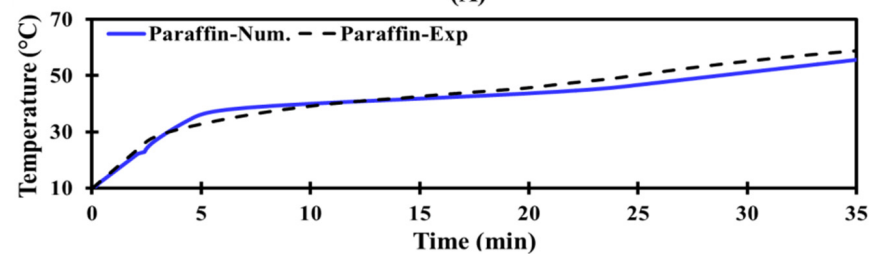

(B)

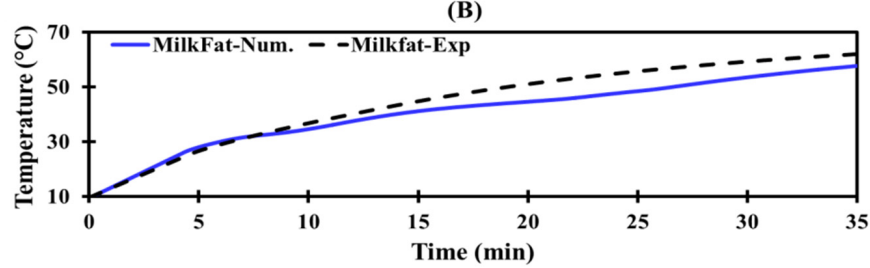

(C)

Figure 12. Comparison between simulation and experimental Time-temperature profiles under NV for: (A) salt; (B) paraffin; and (C) milk fat.

For milk fat, Figure 12C depicts a larger deviation between experimental and simulation results at higher temperatures. The deviation may have resulted from the uncertainty in the convective heat loss coefficient and measured thermo-physical properties (especially melting point, heat capacity and heat of fusion) derived from DSC temperature hysteresis because of broader melting range and non-uniform composition of milk fat, which is difficult to model. In the DSC curve, the PCM showed more than one melting peak (representing at least two solidus and two liquidus temperatures) while the model can allow only one solidus and one liquidus temperature, which may have caused deviation as well. The problem can be handled for a milk fat sample of one melting peak and narrow melting range by refining butter, which is under consideration for future research.

Generally, at lower temperatures, very good agreement is achieved between the experimental and numerical results, while at higher temperature, the deviation in all cases appears after PCM melting phase. The root-mean-square error (RMSE) and coefficient of determination $\left(R^{2}\right)$ are computed to quantify the deviations between simulation and experimental results. The resulting error parameters for all PCMs indicate a very good agreement, with RMSE and $R^{2}$ yielding $1.9^{\circ} \mathrm{C}$ and $0.962,2.5^{\circ} \mathrm{C}$ and 0.972 , and $2.2^{\circ} \mathrm{C}$ and 0.981 for salt, paraffin, and milk fat, respectively.

\subsubsection{Parametric Influences on Thermal Management}

The validated numerical model is employed to study the influence of PCM properties on the thermal management performance to identify the most optimum PCMs. Thermo-physical properties of paraffin wax (Table 4) were used as a reference to conduct the simulation with thermal energy storage capacity of $1.15 \mathrm{~kJ}$. The values of thermal conductivity, density, melting range and melting points were varied to study their influence on PCM performance. Figure 13 shows the effect of PCM thermal conductivity (upper horizontal axis) and PCM density (bottom horizontal axis) on temperature rise on left vertical axis and time to melt on right vertical axis. The relationship between density and temperature rise $(\rho-\Delta T)$, density and time to melt $\left(\rho-t_{m}\right)$, conductivity and temperature rise $(K-\Delta T)$ and conductivity and time to melt $\left(K-t_{m}\right)$ is presented in Figure 13. The PCMs show a range of thermal conductivities starting from $0.14 \mathrm{~W} / \mathrm{m} \cdot \mathrm{K}$ (for fatty acids) to $0.8 \mathrm{~W} / \mathrm{m} \cdot \mathrm{K}$ (for salts hydrates), so the same range is applied in the simulations. 


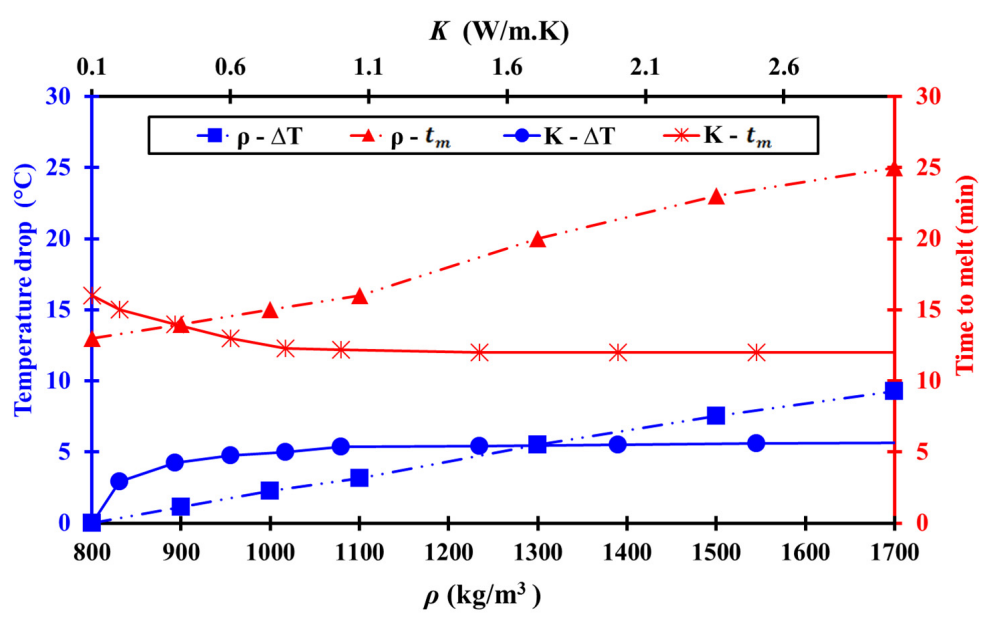

Figure 13. The effects of increasing the thermal conductivity of PCM (Paraffin) on the temperature drop of HS and time for the material to melt completely.

Figure 13 shows that as the $K$ increases from 0.1 to $0.4 \mathrm{~W} / \mathrm{m} \cdot \mathrm{K}$, a temperature drop of $5{ }^{\circ} \mathrm{C}$ and reduction in PCMs' time to melt by $2 \mathrm{~min}$ is observed. The temperature drop and time to melt become less affected with further increase in $K$ and becomes unnoticeable at $K=0.8 \mathrm{~W} / \mathrm{m} \cdot \mathrm{K}$. The limiting conductivity in this case can be caused by overwhelmingly applied metallic fins in the present HS design and may not have room for more conductivity enhancement. It can be concluded that for the HS design under investigation, the thermal conductivity of $0.8 \mathrm{~W} / \mathrm{m} \cdot \mathrm{K}$ (for salt hydrate) is the maximum impacting conductivity. It means that the addition of thermal conductivity enhancers (like nanoparticles) into salt hydrate is not expected to improve the system performance.

However, since the paraffin waxes used in this study possess less thermal conductivity $(0.2 \mathrm{~W} / \mathrm{m} \cdot \mathrm{K})$, they can be improved by adding nanoparticles or other $\mathrm{K}$-enhancers to moderately increase their thermal performance. In future work, the conductivity enhancement can be studied with various HS designs that have various fin densities and arrangements.

In the case of PCM based cooling systems, the PCM density is an important parameter as it would dictate the size of PCM containment and would eventually affect device volume. The higher density PCM can be packed in smaller volumes with same weight and thermal energy storage capacity compared to the lower density PCM given that the other parameters are fixed thereby reducing device size and cost. The effect of changing the density values from the lowest value of $802 \mathrm{~kg} / \mathrm{m}^{3}$ (paraffin wax) to the highest value of $1700 \mathrm{~kg} / \mathrm{m}^{3}$ (salt hydrate) is addressed. It can be seen that as the material density increases, the temperature drop increases linearly reaching up to $10^{\circ} \mathrm{C}$. On the other hand, an increase in density will increase the time to complete melting by $10 \mathrm{~min}$.

Figure 14a shows the effect of different melting ranges on the temperature rise of the heat generator surface $\left(T_{b}\right)$. The PCMs melting range has been selected to start at $37^{\circ} \mathrm{C}$ being substantially above the room temperature $\left(25^{\circ} \mathrm{C}\right)$ and ends at $58^{\circ} \mathrm{C}$ being well below the device safety temperature of $60^{\circ} \mathrm{C}$. The start is selected to assure that all PCMs are completely in the solid phase when the device is not operating and end is selected to stabilize device temperature below safety temperature. The effect of fixing the same melting start and keep increasing end of melting temperature to mark a widening melting range (Figure 14a) is compared with fixing the same narrow melting range and shifting up start of melting (Figure 14b). The result indicates that when the melting point is fixed at $37^{\circ} \mathrm{C}$ (pure $\mathrm{PCM}$ ), the melting curve is nearly isothermal showing a temperature control within the narrow range. When $\mathrm{PCM}$ melting range becomes wider $\left(37-43^{\circ} \mathrm{C}, 37-48^{\circ} \mathrm{C}\right.$ and $\left.37-53^{\circ} \mathrm{C}\right)$, the melting curve deviates further from isothermal and a large difference in melting start and completion is observed which results in less stringent temperature control. Additionally, with wider melting ranges, the temperature rises and time to complete melting increases which are detrimental for temperature control applications. 


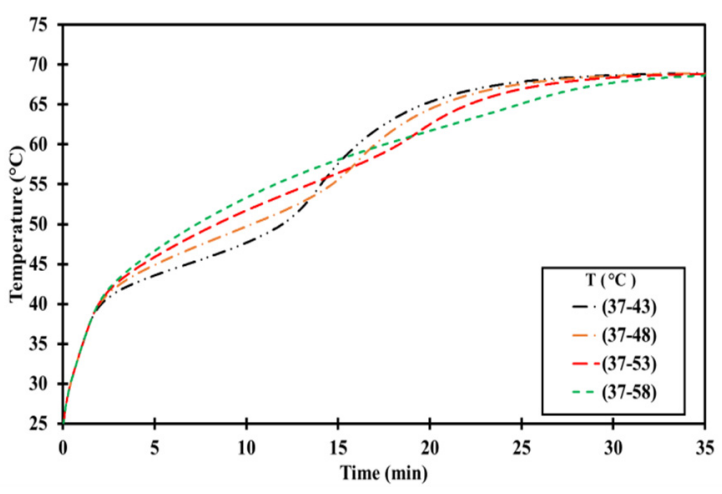

(A)

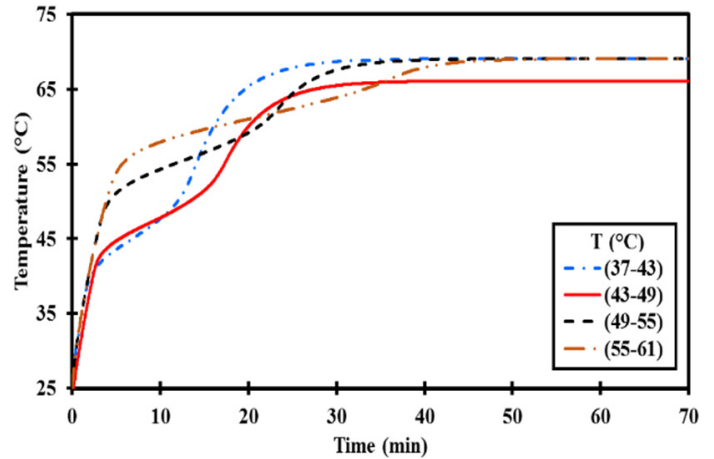

(B)

Figure 14. The effect of PCM melting characteristics on the HS temperature drop: (A) with a fixed start of melting and increasing melting range; and (B) with a fixed melting range and shifting melting start.

Figure $14 \mathrm{~b}$ shows that as the melting start is shifted upward, the temperature rises and the phase change boundaries become less visible. It indicates that for the studied power input and PCM, the melting point ranges of $37-43^{\circ} \mathrm{C}$ and $43-49^{\circ} \mathrm{C}$ are optimal while the upper melting points achieve less stringent temperature control. For phase change temperature for various power inputs and heat sink designs, however, need more detailed simulation investigations and will be studied in future research. Conclusively, a pure PCM with sharp melting point and narrow melting range is recommended for strict temperature control applications.

\section{Conclusions}

This paper addresses the effect of using three PCMs (salt, paraffin and milk fat) as thermal regulators for cooling of electronics packaging. Different investigations employing empty HS and HS filled with PCM under NV and FV are tested. The experiments are conducted at four heat loads intensities ranging from $4027 \mathrm{~W} / \mathrm{m}^{2}$ to $9748 \mathrm{~W} / \mathrm{m}^{2}$. It is observed that under natural ventilation up to $6 \mathrm{~W}$ heat load, HS only can maintain device temperature below safety limit $\left(60^{\circ} \mathrm{C}\right)$ for only $5 \mathrm{~min}$. When PCMs are included in HS, for the same heat load up to $6 \mathrm{~W}$, the time for device to operate under safety temperature extends to $15 \mathrm{~min}$. Under forced ventilation, the HS only can operate the device under safety temperature for $5 \mathrm{~min}$ up to $10 \mathrm{~W}$, for $15 \mathrm{~min}$ up to $6 \mathrm{~W}$ and for $60 \mathrm{~min}$ up to $4 \mathrm{~W}$ only. When the PCMs are included in the HS under forced ventilation, the device can be maintained below safety temperature by all the three PCMs for $5 \mathrm{~min}$ up to $10 \mathrm{~W}$, for $15 \mathrm{~min}$ up to $8 \mathrm{~W}$ by paraffin and milk fat while up to $10 \mathrm{~W}$ by salt hydrate and for $60 \mathrm{~min}$ up to $6 \mathrm{~W}$ by all of the PCMs. It emphasizes that the PCM amount needs to be optimized for a certain duration of temperature control at various heat loads. Comparison between experimental results and numerical predictions yields a very good agreement as represented by $R^{2}$ and RMSE varying in the range of 0.93-0.98 and $1.9-2.5^{\circ} \mathrm{C}$, respectively. A parametric study is conducted through the validated simulation model concluding that a right selection of the melting point, thermal conductivity and density can remarkably improve temperature control performance of the PCMs. The following general conclusions are drawn from the presented research:

1. A time lag in temperature rise ensues due to increased heat absorption by PCMs.

2. PCMs under both NV and FV achieve lower temperature than the HS-only at all tested heat loads.

3. At higher heat fluxes, PCM melts faster implying that the effective time for temperature control is reduced. Consequently, an additional amount of PCM would be required for prolonged operation.

4. No clear phase transition boundaries could be traced for milk fat due to its wider melting range contrary to salt hydrate and paraffin. 
Acknowledgments: The authors would like to acknowledge the support from the UAE University Research Affairs through Grant No. G00001181.

Author Contributions: Ahmad Hasan, Ali Assi and Hassan Hejase conceived and designed the experiments; Ahmad Hasan and Shaimaa Abdelbaqi performed the experiments; Hassan Hejase analyzed the data; Mohammad O. Hamdan contributed reagents/materials/analysis tools; Shaimaa Abdelbaqi wrote the paper.

Conflicts of Interest: The authors declare no conflict of interest.

\section{Abbreviations}

The following abbreviations are used in this manuscript:

\begin{tabular}{|c|c|}
\hline$d$ & Mesh cell size (mm) \\
\hline K & Thermal conductivity $(\mathrm{W} /(\mathrm{m} \cdot \mathrm{K}))$ \\
\hline$T$ & Temperature $\left({ }^{\circ} \mathrm{C}\right)$ \\
\hline$t$ & Time $(\mathrm{s})$ \\
\hline$\rho$ & Density $\left(\mathrm{kg} / \mathrm{m}^{3}\right)$ \\
\hline$H$ & Enthalpy $(\mathrm{kJ} / \mathrm{kg})$ \\
\hline $\mathrm{u}_{j}$ & Velocity vector $(\mathrm{m} / \mathrm{s})$ \\
\hline$\beta^{\prime}$ & Liquid Fraction \\
\hline$c_{p}$ & Specific heat capacity $(\mathrm{J} /(\mathrm{kg} \cdot \mathrm{K}))$ \\
\hline$L^{p}$ & Latent heat capacity $(\mathrm{kJ} / \mathrm{kg})$ \\
\hline$h$ & Heat transfer coefficient, $\left(\mathrm{W} / \mathrm{m}^{2} \cdot \mathrm{K}\right)$ \\
\hline$S_{h}$ & Source term due to melting $\left(\mathrm{W} / \mathrm{m}^{3}\right)$ \\
\hline $\mathrm{Nu}$ & Nusselt number \\
\hline $\mathrm{Pr}$ & Prandtl number \\
\hline $\operatorname{Re}$ & Reynolds number \\
\hline$V$ & Velocity $(\mathrm{m} / \mathrm{s})$ \\
\hline$v$ & Viscosity $\left(\mathrm{m}^{2} / \mathrm{s}\right)$ \\
\hline$\sigma$ & Stephan-Boltzmann constant $\left(5.67 \times 10^{-8}\left(\mathrm{~W} /\left(\mathrm{m}^{2} \mathrm{~K}^{4}\right)\right)\right.$ \\
\hline$\varepsilon$ & Emissivity \\
\hline$\Delta T$ & Temperature drop $\left({ }^{\circ} \mathrm{C}\right)$ \\
\hline ATD & Average Temperature Difference \\
\hline $\mathrm{DAQ}$ & Data Acquisition \\
\hline $\mathrm{DC}$ & Direct Current \\
\hline DSC & Differential Scanning Calorimetry \\
\hline EPS & Expanded Polystyrene \\
\hline FV & Forced Ventilation \\
\hline HS & Heat Sink \\
\hline LABVIEW & Laboratory Virtual Instrument Engineering Workbench \\
\hline LHTMS & Latent Heat Thermal Management System \\
\hline NV & Natural Ventilation \\
\hline PCM & Phase Change Material \\
\hline$R^{2}$ & Coefficient of Determination \\
\hline RMSE & Root-Mean-Square-Error \\
\hline Liq & Liquidus \\
\hline Sol & Solidus \\
\hline ref & Reference \\
\hline$\infty$ & Infinity \\
\hline $\mathrm{rad}$ & Radiation \\
\hline con & Convection \\
\hline$f$ & Film \\
\hline $\mathrm{amb}$ & Ambient \\
\hline $\mathrm{m}$ & Melt \\
\hline sur & Surface \\
\hline RS & Right side \\
\hline LS & Left side \\
\hline $\mathrm{R}$ & Rear \\
\hline F & Front \\
\hline $\mathrm{T}$ & Top \\
\hline Vert & Vertical \\
\hline Horiz & Horizontal \\
\hline
\end{tabular}




\section{Appendix}

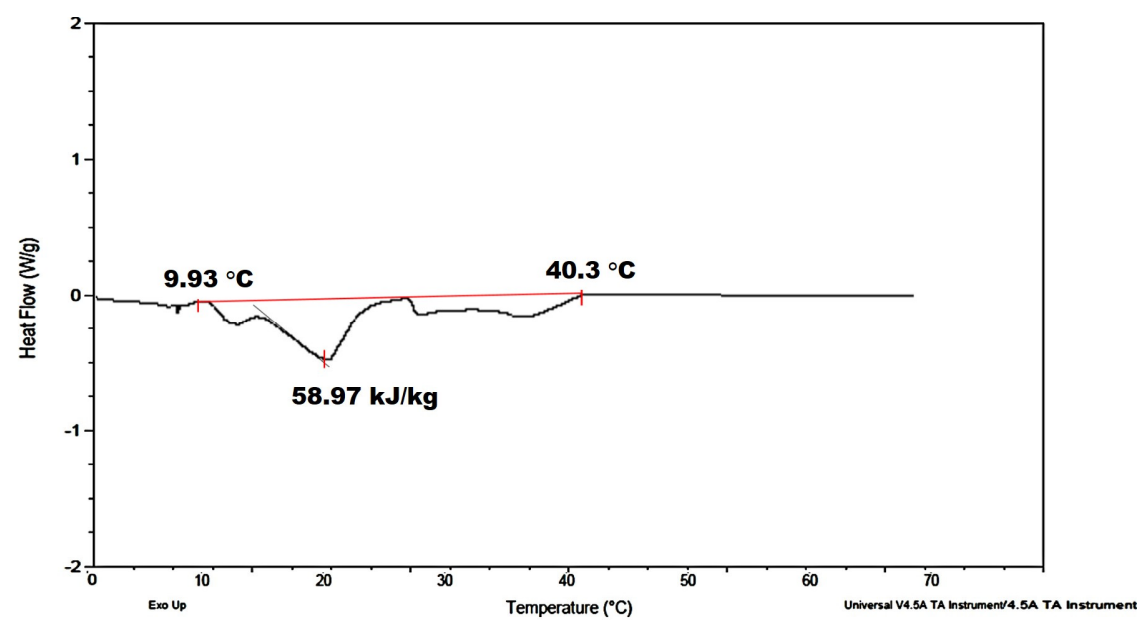

(A)

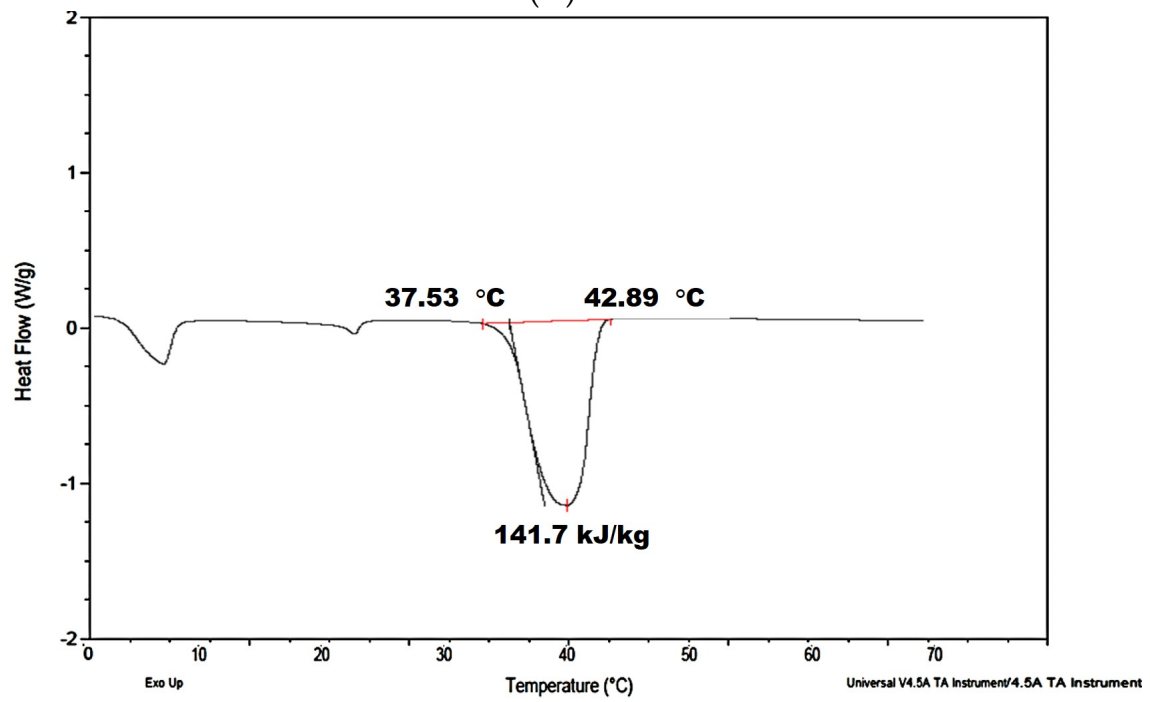

(B)

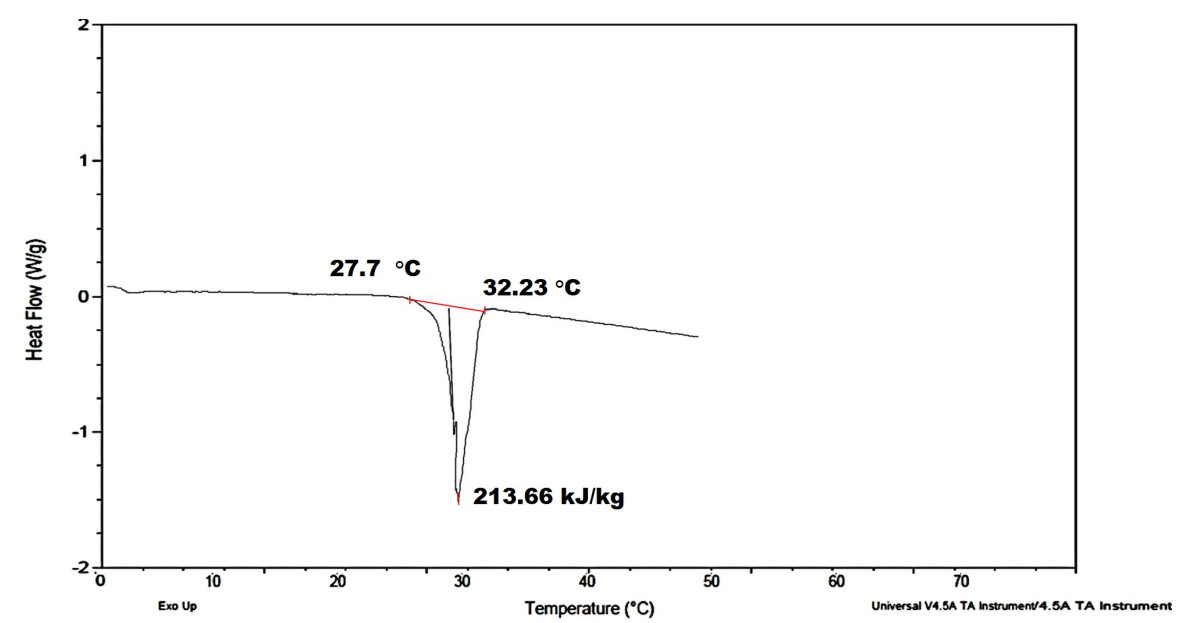

(C)

Figure A1. Differential Scanning Calorimetry (DSC) heating curve for (A) Milk fat, (B) Paraffin and (C) Salt. 


\section{References}

1. Mondal, S. Phase change materials for smart textiles-An overview. Appl. Therm. Eng. 2008, 28, 1536-1550. [CrossRef]

2. Bajaj, P. Thermally sensitive materials. In Smart Fibres, Fabrics and Clothing; Tao, X.M., Ed.; Woodhead Publishing Ltd.: Cambridge, England, 2001; pp. 58-82.

3. Hamdan, M.; Al-Hinti, I. Analysis of heat transfer during the melting of a phase-change material. Appl. Therm. Eng. 2004, 24, 1935-1944. [CrossRef]

4. Kim, S.; Drzal, L. High latent heat storage and high thermal conductive phase change materials using exfoliated graphite nano-platelets. Sol. Energy Mater. Sol. Cells 2009, 93, 136-142. [CrossRef]

5. Khateeb, S.; Farid, M.; Selman, J.; Al-Hallaj, S. Design and simulation of a lithium-ion battery with a phase change material thermal management system for an electric scooter. J. Power Sources 2004, 128, $292-307$. [CrossRef]

6. Tan, F.L.; Fok, S.C. Thermal management of Mobile Phones Using Phase Change Materials. In Proceedings of the IEEE 9th Electronics Packaging Technology Conference, Singapore, Singapore, 10-12 December 2007; pp. 836-842.

7. Kandasamy, R.; Wang, X.; Mujumdar, A. Transient cooling of electronics using phase change material (PCM)-based heat sinks. Appl. Therm. Eng. 2008, 28, 1047-1057. [CrossRef]

8. Shatikian, V.; Ziskind, G.; Letan, R. Numerical investigation of a PCM-based heat sink with internal fins. Int. J. Heat Mass Trans. 2005, 48, 3689-3706. [CrossRef]

9. Sharma, S.D.; Sagara, K. Latent heat storage materials and systems. Int. J. Green Energy 2005, 2, 1-56. [CrossRef]

10. Marongiu, M.J. Thermal management of outdoor enclosures using phase change materials. Electron. Cool. 1998, 4, 26-29.

11. Weng, Y.-C.; Cho, H.-P.; Chang, C.-C.; Chen, S.-L. Heat pipe with PCM for electronic cooling. Appl. Energy 2011, 88, 1825-1833. [CrossRef]

12. Kandasamy, R.; Wang, X.; Mujumdar, A. Application of phase change materials in thermal management of electronics. Appl. Therm. Eng. 2007, 27, 2822-2832. [CrossRef]

13. Sharma, A.; Tyagi, V.V.; Chen, C.R.; Buddhi, D. Review on thermal energy storage with phase change materials and applications. Renew. Sustain. Energy Rev. 2009, 13, 318-345. [CrossRef]

14. Berroug, F.; Lakhal, E.K.; El Omari, M.; Faraji, M.; El Qarnia, H. Thermal performance of a greenhouse with a phase change material north wall. Energy Build. 2011, 43, 3027-3035. [CrossRef]

15. Zhou, D.; Zhao, C.Y. Experimental investigations on heat transfer in phase change materials (PCMs) embedded in porous materials. Appl. Therm. Eng. 2011, 31, 970-977. [CrossRef]

16. Veerappan, M.; Kalaiselvam, S.; Iniyan, S.; Goic, R. Phase change characteristic study of spherical PCMs in solar energy storage. Sol. Energy 2009, 83, 1245-1252. [CrossRef]

17. N'Tsoukpoe, K.E.; Rammelberg, H.U.; Lele, A.F.; Korhammer, K.; Watts, B.A.; Schmidt, T.; Wolfgang, K.L. A review on the use of calcium chloride in applied thermal engineering. Appl. Thermal Eng. 2015, 75, 513-531. [CrossRef]

18. Gawron, K.; Schröder, J. Properties of some salt hydrates for latent heat storage. Int. J. Energy Res. 1977, 1, 351-363. [CrossRef]

19. Sharma, S.D.; Kitano, H.; Sagara, K. Phase change materials for low temperature solar thermal applications. Res. Rep. Fac. Eng. 2004, 29, 31-64.

20. Gruszkiewicz, M.S.; Simonson, J.M. Vapor pressures and isopiestic molalities of concentrated $\mathrm{CaCl}_{2}(\mathrm{aq})$, $\mathrm{CaBr}_{2}$ (aq), and $\mathrm{NaCl}$ (aq). J. Chem. Thermodyn. 2005, 37, 906-993. [CrossRef]

21. Kenisarin, M.; Mahkamov, K. Salt hydrates as latent heat storage materials: Thermophysical properties and costs. Solar Energy Mater. Sol. Cells 2016, 145, 255-286. [CrossRef]

22. Tyagi, V.V.; Buddhi, D. Thermal cycle testing of calcium chloride hexahydrate as a possible PCM for latent heat storage. Sol. Energy Mater. Sol. Cells 2008, 92, 891-899. [CrossRef]

23. Kaygusuz, K. Experimental and theoretical investigation of latent heat storage for water based solar heating systems. Energy Convers. Manag. 1995, 36, 315-323. [CrossRef] 
24. Cabeza, L.F.; Illa, J.; Roca, J.; Badia, F.; Mehling, H.; Hiebler, S. Middle term immersion corrosion tests on metal-salt hydrate pairs used for latent heat storage in the 32 to $36^{\circ} \mathrm{C}$ temperature range. Mater. Corros. 2001, 52, 748-754. [CrossRef]

25. Leoni, N.; Amon, C.H. Transient thermal design of wearable computers with embedded electronics using phase change materials. ASME-PUBLICATIONS-HTD 1997, 343, 49-56.

26. Farid, M.M.; Khudhair, A.M.; Ali, K.S.; Al-Hallaj, R.S. A review on phase change energy storage: Materials and applications. Energy Convers. Manag. 2004, 45, 1597-1615. [CrossRef]

27. Nayak, A.O.; Gowtham, M.R.; Vinod, R.; Ramkumar, G. Analysis of PCM Material in Thermal Energy Storage System. Int. J. Environ. Sci. Dev. 2011, 2, 437. [CrossRef]

28. Freund, M.; Mózes, G.; Jakab, E. Paraffin Products: Properties, Technologies, Applications; Elsevier: Amsterdam, The Netherlands, 1982; Volume 121, pp. 444-997.

29. Farid, M.; Mohamed, A. Effect of Natural Convection on the Process of Melting and Solidification of Paraffin Wax. Chem. Eng. Commun. 1987, 57, 297-316.

30. Farid, M.; Kanzawa, A. Thermal Performance of a Heat Storage Module using PCM's with Different Melting Temperatures: Mathematical Modeling. J. Sol. Energy Eng. 1989, 111, 152-157. [CrossRef]

31. Elgafy, A.; Lafdi, K. Effect of carbon nanofiber additives on thermal behavior of phase change materials. Carbon 2005, 43, 3067-3074. [CrossRef]

32. Fukai, J.; Hamada, Y.; Morozumi, Y.; Miyatake, O. Effect of carbon-fiber brushes on conductive heat transfer in phase change materials. Int. J. Heat Mass Transf. 2002, 45, 4781-4792. [CrossRef]

33. Watson, E.L. Thermal properties of butter. Can. Agric. Eng. 1975, 17, 68-71.

34. Alfa-Laval. Dairy Handbook; AB Publishing: London, UK, 1980.

35. Finglas, P.M.; Toldra, F. Butter: Properties and Analysis. In Encyclopedia of Food and Health, 1st ed.; Elsevier: Amsterdam, Netherlands, 2016; Volume 1, pp. 540-544.

36. Reyes, V.C. Homemade Butter. Available online: https://scienceandfooducla.wordpress.com/2013/05/28/ homemade-butter/ (accessed on 6 August 2015).

37. Rajeev, M. The Temperature Ratings Of Electronic Parts. Electron. Cool. 2004, 10, 20.

38. Minges, M. Electronic Materials Handbook; ASM International: Materials Park, OH, USA, 1989; Volume 1.

39. Tgrease-2500 (Thermal Grease). Available online: http://www.lairdtech.com/products/tgrease-2500 (accessed on 25 September 2015).

40. Lu, T.J.; Evans, A.G.; Hutchinson, J.W. The effects of material properties on heat dissipation in high power electronics. J. Electron. Packag. 1998, 120, 280-289. [CrossRef]

41. Lamberg, P.; Lehtiniemi, R.; Henell, A.M. Numerical and experimental investigation of melting and freezing processes in phase change material storage. Int. J. Therm. Sci. 2004, 43, 277-287. [CrossRef]

42. Smith, W.F.; Hashemi, J. Foundations of Materials Science and Engineering, 4th ed.; McGraw-Hill: New York, NY, USA, 2006; pp. 318-320.

43. Susman, G.; Dehouche, Z.; Cheechern, T.; Craig, S. Tests of prototype PCM 'sails' for office cooling. Appl. Therm. Eng. 2010, 31, 717-726. [CrossRef]

44. Brent, A.D.; Voller, V.R.; Reid, K.J. Enthalpy porosity technique for mode1ing convection-diffision phase change. Numer. Transfer. 1988, 1, 97-318.

45. Egolf, P.W.; Manz, H. Theory and modelling of phase change materials with and without mush regions. Int. J. Heat Mass Transfer. 1994, 37, 2917-2624. [CrossRef]

46. Kuznik, F.; Virgone, J. Experimental investigation of wallboard containing phase change material: Data for validation of numerical modelling. Energy Build. 2009, 41, 561-570. [CrossRef]

47. Cengel, Y. Heat and Mass Transfer: A Practical Approach, 3rd ed.; McGraw-Hill: Boston, MA, USA, 2007.

48. SP-29 Data Sheet (Salt Hydrate Hexahedra). Available online: http://www.rubitherm.eu/media/products/ datasheets/Techdata_SP29Eu_EN_02062016.PDF (accessed on 27 August 2015).

49. RT-42 Data Sheet (Paraffin Wax). Available online: http://www.rubitherm.eu/media/products/datasheets/ Techdata_-RT42_EN_09052016.PDF (accessed on 6 August 2015). 
50. Glenn Elert. Density: The Physics Hyper Text Book. Available online: http://physics.info/density/ (accessed on 25 August 2015).

51. Bürkle GmbH. Viscosity of Liquids. 2011. Available online: http://www.buerkle.de/media/files/ Downloads/Viscosity_EN.pdf (accessed on 20 January 2016).

(c) 2016 by the authors; licensee MDPI, Basel, Switzerland. This article is an open access article distributed under the terms and conditions of the Creative Commons Attribution (CC-BY) license (http://creativecommons.org/licenses/by/4.0/). 